\title{
LEGAL-SURVEYING DOCUMENTATION IN THE REGISTRATION OF RIGHTS TO PROPERTIES OF THE TREASURY AND OF TERRITORIAL SELF- GOVERNMENT UNITS - CASE STUDY OF POLAND
}

\author{
Katarzyna Sobolewska-Mikulska \\ Department of Cadaster and Land Management \\ Warsaw University of Technology, Warsaw, Poland \\ e-mail:katarzyna.sobolewska@pw.edu.pl \\ Agnieszka Cienciała \\ Department of Geomatics, Cadaster and Real Estates \\ Kielce University of Technology, Kielce, Poland \\ e-mail:acienciala@tu.kielce.pl
}

\begin{abstract}
The Act of 21 August 1997 on Real Estate Management imposes on district governors within the management of the Treasury-owned real estates, as well as the commune head, the mayor or city mayor - in the case of the real estate resources of the commune, poviat management - to the poviat real estate resource and voivodship board, in relation to the provincial real estate resource - the obligation to undertake actions in court proceedings, particularly in cases concerning ownership or other property rights. In addition, it obliges them to submit applications for the establishment of a land register and for its updating.

In practice, there are numerous cases of negligence in the registration of such properties, in the updating of their designation and demonstration of rights that affect the legal status. For the purpose of this publication, examples of legal-surveying documentation were analyzed to indicate the most common problems encountered in Poland in the regulation process of the legal status of properties, and the typical content of maps for legal purposes was systematized. In addition, selected approaches used in the area of the registration of rights to properties in other countries of the world were indicated.
\end{abstract}

Key words: real estate management, maps for legal purposes, unregulated legal status, public properties.

JEL Classification: H82, K11, L85, Q15.

Citation: Sobolewska-Mikulska, K., Cienciała, A. (2020). Legal-surveying documentation in the registration of rights to properties of the treasury and of territorial self-government units - case study of Poland. Real Estate Management and Valuation, 28(2), 76-88.

DOI: https://doi.org/10.1515/remav-2020-0017

\section{Introduction}

Public real estate management systems are different throughout the world. According to the guidelines concerning land administration prepared by United Nations in 1996 (United Nations 1996) the State is a major landowner in all societies and its property must be protected. Among others, the State needs to manage its property assets and ensure their efficient use and upkeep every bit as much as does the private citizen. There are threats to the interest of the assets of the Treasury and of territorial self-government units, such as illegal occupation of land ("squatting") and acquisition of 
land by "adverse possession", trespass upon property, boundary conflicts, etc. The solution to these problems is efficient land management. Good governance, as a very broad concept accounting for various processes in land management and land administration, is one of the management models in the public sector. It supports decision making and assists the public administration in the process of fulfilling its statutory duties (Klimach, et al., 2018).

The Act of 21 August 1997 on Real Estate Management, regulating the management of the properties owned by the State Treasury and local government units in Poland, imposes on district governors (starosta) within the management of the Treasury-owned real estates, as well as a commune head (wojt), mayor or city mayor - in the case of real estate resources of the commune, poviat management - to the poviat real estate resource and voivodship board, in relation to the provincial real estate resource - the obligation to undertake actions in court proceedings, particularly in cases concerning the ownership or other property rights in the real estate. Such activities are closely related to the issue of regulating the legal status of state-owned and state-possessed real estates, which was initiated along with the transformation of the political system in 1989. They are now continued, but many districts (powiat) still have a large percentage of state-owned real estates without regulated legal status in the form of established land and mortgage registers or other documents that certify the right of ownership. In addition, the act obliges the above-mentioned bodies to submit applications for the establishment of a land and mortgage register for real estate from the resources and for an entry in the land and mortgage register. When implementing the above mentioned tasks, the authorities encounter numerous difficulties that affect the length of proceedings, require time-consuming analyses of archived materials and carry the need for surveying and legal documentation.

\section{Registering rights to properties and their designation}

Due to diverse historical, social, and economic conditions, the specificity of legal regulations and technical solutions related to the registration of rights to land properties varies (Bełej, et al., 2003; Trembecka, 2016). This results from the rules of functioning and substantive scope of particular systems of information on land property. They are regulated by the independent internal arrangements of each country (Sobolewska-Mikulska \& Sajnóg, 2018). There is widespread recognition that the function of land registration is to provide a safe and certain foundation for the acquisition and disposal of rights to properties. There are countries, such as Finland, Sweden, Lithuania or Hungary, where there is one integrated real estate information system recording both the legal status and designation of real estates, i.e. area, land use, boundaries of parcels. In Hungary, for example, there is one institutional network, named Land Office, responsible for the registration of legal transactions and cadastral mapping changes, as well as dealing with other land and real estate property related activities (Osskó, 2008). The author adds, however, that as many countries in Western and Central Europe, from the middle of the 19th century, real estates used to be double registered, which caused a lot of uncertainty in the use and the need for parallel data updating and registration. Such circumstances led to the decision in 1971 to establish unified registration, including all the data (mapping and legal) concerning the legal status of real estates. The land registration was completed in 1981 and became a multipurpose system - The Unified Land registry System. Most European countries have one national, centralized land registration system but there are also cases of local systems based on different rules, such as those of German federal states. In regard to the organization of land registers, a register may be maintained by a judicial authority (as it is e.g. in Poland, Austria, Croatia, Denmark, Estonia, Latvia, Germany, Slovenia) or an administrative body (e.g. in Belgium, the Czech Republic, England, France, Greece, Hungary, Ireland, Italy, Slovakia, Spain and Portugal) (Kaczorowska, 2018). In countries such as Poland, Austria, the Czech Republic, Croatia, Estonia, Finland, Germany, Hungary, Lithuania, Romania, Slovakia, Slovenia, but also in Denmark, England and Wales, Spain, Portugal and Sweden, the subject of registration are rights on land (interests), whereas in Belgium, Bulgaria, France, Italy, Luxembourg and the Netherlands, registers of deeds collecting documents regarding land transactions are maintained. According to Kaczorowska (2018), some land registers of the second type are well organized and improved, which can be observed on the examples of the French and Dutch land registers. The role of cadasters in providing legal bases for land ownership rights and land readjustments must continue (Choi, 2020). The author adds that methods that deal with cadasters must also be continuously updated for a smart land management policy. 
In many parts of Europe, such as in Turkey, Germany or Poland, however, the cadaster evolved as a system supporting land taxation, while records concerning the legal status were entered in land books. Although there are strict rules concerning entering of data into both of the databases, the duality of the registers leads to inconsistencies between the two registers, duplication of effort, as well as more complex processes of land administration. Both the legal component (land registry) and mapping component (cadaster) of the land registration system are organized by a unique institution (The General Directorate of Land Registry and Cadaster) in Turkey. Cadaster and mapping facilities are performed by Cadaster Offices, while land registry facilities are performed by Land Registry Offices (Ulger, et al., 2015). Greece and Romania are both EU countries that still do not have a complete and updated cadaster for the entirety of their territories and are currently running parallel property registration projects which are closely monitored and reviewed by international and local experts (Potsiou, et al., 2020). The Hellenic cadastral project was initiated in 1995 and is planned to be finalized by the end of 2020, whereas the Romanian cadastral project was initiated in 1996 and will achieve full operation by the end of 2023. In many jurisdictions, property rights in relation to land are registered on 2D parcels (Stoter, et al., 2017). The authors commented that as long as there is only one owner of the land, this mode of registration is sufficient to represent the legal situation, but in specific, multi-level property situations, a 3D approach has important advantages for the cadastral registration approach. The physical and legal complexities of the built and natural environment prompt new concepts and definitions of real property units in order to meet the demands of a today's society and to balance private and public spatial interests (Drobež, et al. 2017). The state of the cadaster in the world differs. Many jurisdictions have defined their own cadastral data models. However, none of them can fully support the requirements of 3D cadasters. Slovenia, for example, introduced the building cadaster alongside the land cadaster in 2000 (Aien, et al., 2017). The cadaster in the Netherlands (in collaboration with the Delft University of Technology) has developed a methodology to improve the registration in multi-level property rights situations through the use of a 3D PDF. On the contrary, in Turkey, by 2013 only 7\% of the whole cadastral maps were in digital format. According to (Demir, et al., 2008), Turkish cadastral bases did not contain sufficient information to be converted to digital system in accordance with field.

In Poland, the following two systems contain information concerning land: the land registry and the cadaster. The land registry contains information concerning legal objects (land parcels, buildings and apartment units). This information generally concerns description and designation, rights, restrictions and responsibilities (including mortgages). Cadastral data mainly consist of spatial descriptions, attributes, values and the corresponding official documents of legal objects (Bydłosz, et al., 2018). The data that are entered into the database of the cadaster must be absolutely reliable. This means that any entry into the cadastral database can only be made based on relevant documents. These include, e.g., notarial deeds, final and legally binding court decisions, final administrative decisions, official copies of land and mortgage registers, etc. (Puniach et al. 2018). The use of poor quality geodesic materials contained in the databases of the real estate's cadaster, for the purposes of performing surveying tasks in real estate management, generates further errors in the resource (Kotlarz, 2017). In an era when information is the main strategic resource, there is a growing need for comprehensive spatial information, including cadastral information, which necessitates the continuous modernization of cadastral systems (Dawidowicz \& Źróbek, 2018). The quality and consistency of data are determined by numerous factors, including the terrain, the applied devices and technologies, as well as the legal requirements in different European Union (EU) countries (Kocur-Bera \& Stachelek, 2019). According to the United Nations (2005), in case of dual registers, there are difficulties in regulating the flow of information to and from the cadaster and the register of property rights, as well as the lack of formalized data exchange between systems. This can result in repetition and additional expenses with duplication of effort and more complex processes of land administration. For instance, cadastral records in Serbia have encountered numerous problems in previous years, such as the existence of different institutions responsible for the management of land data and real properties, storing data in multiple places, data storage in analog form, discrepancy in records in relation to the actual situation, separation of alphanumeric and geometric data, complex structure of the records as a result of inheriting data from different sources, poor performance of searching for and updating of data, and the lack of a standard format for data exchange (Radulović, et al., 2017). The authors emphasize that some of the problems have been resolved, though many have 
not, which can lead to data redundancy, re-implementing functionality, and disturbed correctness of the data.

In many parts of Europe, property records have not been adequately maintained or were destroyed during World War II. In Bosnia-Herzegovina, many more were devastated during the 1992-1995 war. Property books often conflict with the cadaster and usually fail to represent the actual situation in the field (Rabenhorst, 2000). The author adds that, in Croatia, land registers continue to be somewhat unreliable, probably for similar reasons, but are regarded as improving. The incompleteness and fragmentation of land records were also indicated as major land administration issues faced by Bulgaria in the late 1990s.

Analyzing the issue of credibility of the data recorded in the registers, it is worth emphasizing that, in some countries, they are treated as primary evidence, not definitive proof. On the other hand, in some systems, such as the English registration of title to land, the State then guarantees the details recorded in the register, so that if a mistake were to occur, compensation would be paid (United Nations, 1996). What is interesting, although the UK has compulsory land registration and proof of title is through entry in a Torrens-style land register, there is no central record of the precise location of boundaries (Grover, 2008). In the Netherlands, although there is technically no guarantee of ownership, the integrity of the system is high enough for landowners to have full confidence in their rights. In Bulgaria, in general terms, the state is not liable for damages caused by incorrect data kept in the property register. Registered real rights can be contested in court (Evtimov, 2002). In Poland, there is a so-called warranty of public trust in land and mortgage registers. The buyers, who in good faith (did not know and could not easily find out about the actual legal status of the property before) purchased the property from the person entitled according to the contents of the land and mortgage register, can effectively demand the release of the property from the owner who is not disclosed in the land and mortgage register. Moreover, the rule is that the owner has to immediately submit an application for publishing his or her right in a land and mortgage register (Article 35 of the Act of 6 July 1982 on land and mortgage registers and mortgages), while the courts, authorities of the government administration and of territorial self-government units as well as public notaries, who draft deeds of succession certification, are obligated to notify the court competent to maintain the land and mortgage register of any changes regarding real estate owners (article 36 of the above Act). The Polish legal system does not, however, provide for the commonness of land and mortgage registers within the meaning of their obligatory establishment and maintenance for every single real estate. Therefore, not all real estates possess established land and mortgage registers (Grzesik, et al., 2007).

In the case of Treasury-owned real estates, submitting applications for the establishment of land and mortgage registers and for entry into land and mortgage registers is the obligation of district governors (starosta) and arises from the Real Estate Management Act (Article 23), while in the case of managing the commune-owned real estate, this is the task of the commune head (wojt), mayor or city mayor (Article 25). The significance of the task may be demonstrated by the statement that, until the regulation of the legal status of the Treasury-owned real estates, it is difficult to talk about complete performance of the tasks related to the management of real estate resources of the Treasury (Celarek, 2012).

\section{Cases demanding the regulation of the legal status of properties}

Over the years, in many regions throughout Poland, the activities aimed at regulating the legal status of real estates were insufficient. The activities of public administration in this regard have been noticeably intensified since the effective date of the Act of 7 September 2007 on publishing the right of ownership to the real estate of the Treasury and of territorial self-government units in land and mortgage registers. It aimed, among other things, to eliminate the negligence in the publication of the ownership right to the public sector real estates in land and mortgage registers. The Act imposed an obligation to prepare lists of real estates whose ownership has been transferred, under separate provisions, onto the Treasury, and which are now the property of the Treasury or of the territorial selfgovernment units. Moreover, it introduced an obligation to submit applications for publishing the right of ownership in land and mortgage registers as well as reports on the fulfilment of the obligation to publish the right of ownership. The statutory obligation to regulate the legal status of real estates has been an important factor leading to the intensification of the above mentioned activities aiming to achieve the proper management of real estates, and has revealed the consequences of a series of 
omissions in this regard, which have occurred over the years. There are various reasons for such a situation of unregulated legal status.

During the performance of the assumptions of the Act of 7 September 2007 on publishing the right of ownership to the real estate of the Treasury and of territorial self-government units in land and mortgage registers, the services responsible for real estate management encounter problems causing considerable delays in the fulfilment of the obligation to submit applications for publishing the ownership right in land and mortgage registers. The two amendments of the Act resulted in the change of the time limits for the completion of the property inventory and the publishing of the ownership right in land and mortgage registers. However, taking into consideration the scale of the problem, one may presume that publishing the ownership right is going to take longer than initially assumed. This is explained, among other things, by lack of financial resources for expenditures related to the preparation of geodetic and legal documentation, or for undertaking other actions concerning real estate management, insufficient numbers of staff members, as well as labor consumption of the particular activities related to the performance of statutory duties. An important role in fulfilling the above-mentioned duties are played by maps for legal purposes, without which the disclosure of the ownership of public-law entities in a land and mortgage register would be, in many situations, impossible.

Real estates with an unregulated legal status are defined in Article 113 Sections 6 and 7 of the Real Estate Management Act of 21 August 1997. According to the definition, those are real estates in the case of which - due to a lack of a land and mortgage register, a set of documents or other documents one cannot determine individuals who are entitled to property rights in the real estates, as well as real estates with regard to which no inheritance proceedings have been conducted or such proceedings have not been concluded (in the event where the owner or the perpetual usufructuary is no longer alive). Other definitions can be found in thee literature on the subject. One of them says that the regulation of the legal status of real estates should be understood to mean a process leading to the determination of individuals who are entitled to the ownership of and other property rights in real estate, or surveying and legal proceedings aimed at establishing the scope of the ownership right, by specifying boundary lines (Łuczyński, 2010). In the literature on the subject, the influence of real estates with an unclear legal status on land management is repeatedly indicated. Such a property, among others, extends the time necessary to prepare land for investment projects (Buśko \& Przewięźlikowska, 2016) and may have social consequences (Noszczyk \& Hernik, 2019), such as, for example, potential socio-spatial conflicts and social dissatisfaction (Eliseev, et al., 2015).

\subsection{Data for the analyses and methods}

This paper is based on research conducted on the basis of the experience of the authors gained in the process of preparing legal-surveying documentation for the needs of regulating the legal status of real estates in administrative and court proceedings and literature review. For the purpose of this publication, examples of such documentation concerning cases of real estates from the resources were analyzed to specify problems encountered in the management process of real estates of the Treasury and local government units in Poland. The experimental studies covered twenty randomly selected cases of the above-mentioned maps for legal purposes prepared mainly for the order of the selfgovernment bodies in the process of regulating the legal status of properties. For this purpose, survey records gathered in the surveying documentation center, including the outcome legal-surveying documentation, the source materials on which the documentation was based (including the content of land registers, archival maps and registries, as well as the current data inscribed in the cadaster), and, in some cases, also the court case files, were analyzed. On their basis, cases when maps for legal purposes play a key role have been systematized and their contents indicated.

\subsection{Empirical results}

The studies of the above-mentioned documentation showed the most commonly found problems in the process of regulating the legal status of real estates. Due to the multiplicity of the encountered difficulties which make it impossible to identify the property or to establish a land and mortgage register for a property, attention in this publication was paid only to cases in the solution of which maps for legal purposes play a key role, with only some of them - the most characteristic ones - being indicated. The most commonly found problems in the regulation process of the legal status of properties in Poland were: 
- The lack of the exact knowledge regarding the number of properties from the resource,

- The lack and state of documents confirming the right of ownership to real estates,

- errors in the entries in land and mortgage registers - in the division of real estates, in their inclusion into other registers and in the settlement of their area,

- the need for conducting time-consuming administrative and court proceedings (concerning the ascertainment of the acquisition of the title),

- the lack of synchronization of data presented in land and mortgage registers, and in a cadastre,

- difficulties in reconstructing the scope of rights (the location of boundaries for example as on the day of right acquisition),

- lack of detailed requirements for preparing surveying and legal documentation (for example templates for maps for legal purposes),

- insufficient knowledge of the rules of regulating the legal status of real estates,

For the purpose of the following publication, documentation prepared by a qualified land surveyor for legal purposes - the above-mentioned twenty maps, was analyzed analyzed in terms of its content. In the Table 1, there is a list of the twenty tasks with the specification of the most frequent activities of the surveyor required in the process of preparing the legal-surveying documents for the regulation of the legal status of properties with the indication of the ones that took place in each case.

Table 1

The most frequent activities required in the process of preparing legal-surveying documents for the regulation of the legal status of properties

\begin{tabular}{|c|c|c|c|c|c|c|c|}
\hline 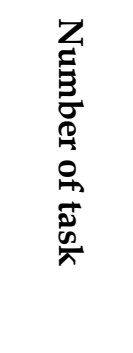 & 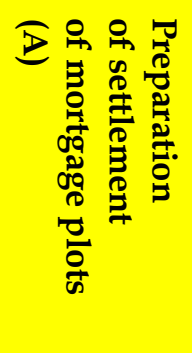 & 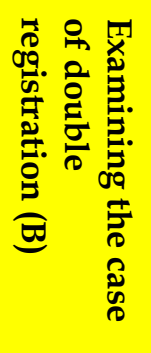 & 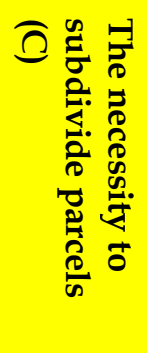 & 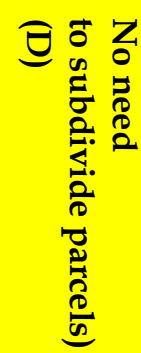 & 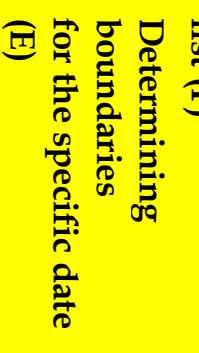 & 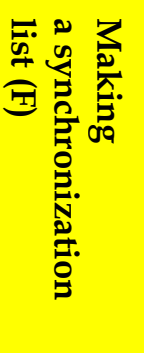 & 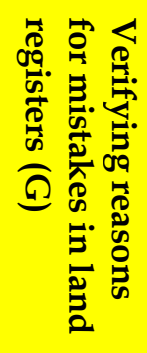 \\
\hline Task 1 & $X$ & & $x$ & & & $X$ & $x$ \\
\hline Task 2 & & & $X$ & & & $X$ & $X$ \\
\hline Task 3 & $\bar{X}$ & & $X$ & & $X$ & $X$ & \\
\hline Task 4 & $X$ & & $X$ & & & $X$ & $X$ \\
\hline Task 5 & $X$ & $X$ & $X$ & & & $X$ & \\
\hline Task 6 & $X$ & & $X$ & $X$ & $X$ & $X$ & \\
\hline Task 7 & $X$ & & $X$ & & & $X$ & \\
\hline Task 8 & $X$ & & $X$ & & & $X$ & \\
\hline Task 9 & $X$ & & & $X$ & & $X$ & \\
\hline Task 10 & $X$ & & $X$ & & & $X$ & \\
\hline Task 11 & $X$ & $X$ & $X$ & & & $X$ & \\
\hline Task 12 & $X$ & $X$ & $X$ & & & $X$ & $X$ \\
\hline Task 13 & $X$ & & $X$ & & & $X$ & \\
\hline Task 14 & $X$ & & $X$ & & $X$ & $X$ & \\
\hline Task 15 & $X$ & & & $X$ & & $X$ & \\
\hline Task 16 & & & & $X$ & $X$ & $X$ & \\
\hline Task 17 & & & & $X$ & $X$ & $X$ & \\
\hline Task 18 & & & & $X$ & $X$ & $X$ & \\
\hline Task 19 & & & $X$ & $X$ & $x$ & & \\
\hline Task 20 & & & & $X$ & $X$ & & \\
\hline
\end{tabular}

Source: own research.

The characterization of the chosen issues has been presented below: 
- lack of synchronization of data presented in land and mortgage registers and in a cadaster,

In the research, in the case of 90\% (18 examples out of 20) of the analyzed maps, there was a need to prepare a synchronization list (F). As it had been mentioned, there are separately maintained registers in Poland, i.e. a land and mortgage register and cadaster. In many cases, difficulty arises due to a lack of synchronization between the data presented in the land and mortgage registers and a cadaster. The problems are connected with the observed series of negligence in the registration of real estates of the Treasury and of territorial self-government units, in the updating of their designation and demonstration of rights to real estates. The lack of synchronization between the designation (data concerning, among other things, the location, the area and the intended use of the real estates) of the real estate appears when such data are not compatible. In such cases, the court - at a request of the owner, may make a correction of such designation on the basis of cadaster data. It may also be affected ex officio. The basis for the correction is an extract from a cadastral survey and - if necessary an extract of the cadastral map or another document that constitutes the basis for the correction of the real estate designation. Discrepancies in designation include differences in the numbering of plots and their area. They may result from the modernization of a land and property register (cadaster), its update as well as arise from the application of more precise measurement and calculation techniques. In some cases, such discrepancies are influenced by historical factors. During the set-up of land registration in the 1970's, according to the definition of a parcel in force at that time, such had to constitute a homogeneous area of possession, not ownership. The boundaries were registered on the land as per the status quo - the scope of possession. No obligation was introduced to update the designation of real estates in the previously established land and mortgage registers which revealed the scope of the property right; therefore, in the majority of cases, no synchronization was done between both registers. Consequently, the existing discrepancies in the designation of real estate's require synchronization in the form of a synchronization list $(\mathrm{F})$ that may constitute the content of a map for legal purposes. To create such type of documents, it is necessary to reconstruct the scope of ownership right presented in a land and mortgage register or being the subject of acquisition by way of a notarial deed, etc. The reconstructed, on the basis of archival materials kept, among others, in the national surveying and cartographic resource or in the resources of the national archives, boundary lines need to be superimposed onto the current structure of the boundaries and the interpretation of which former mortgage parcels (plots of land) correspond to the current record parcels. In the polish legal system, there are not strict rules regulating the form and content of the Synchronization List. This has two kinds of negative effects: the contractors have no outline for preparing such a document, surveying administration cannot specify the legal basis for the refusal to accept the improperly prepared documents in situations which are not obvious (Buśko \& Przewięźlikowska, 2016).

The necessity of synchronizing the designation of property also appears, among others, in the province of ex-Austro-Hungarian territories (Tavolare) in Italy. It is necessary to do this prior to any cadastral update, such as fragmentation, introduction of new building on the map, etc. It is necessary to have only one map representing the description of the property and the rights of the owner, so as to correctly match the actual places with their graphic representation on the maps and in correlation with the connected rights (Passador, 2012). The author emphasizes that, in this way, the differences that still exist between the data of the two systems are progressively erased through the unification of geometries, numbers, extension and rights, and in conformity with both the traveler laws and the cadastral norms.

\section{- lack of documents confirming the right of ownership to real estates and the scope of it,}

What is more, the unregulated legal status of real estates in Poland is very often associated with a lack of proper documentation regarding the right of ownership to the real estate. Incomplete, out of date or contested land records can pose a threat to tenure security and the overall peaceful situation (Todorovski, et al., 2016). Such a situation is frequent in the case of the Treasury-owned properties in Poland, as the land that is held by the State for the benefit of the community is very often poorly documented. The owner of the property is then registered in the cadaster as un-known. There has to be a thorough query carried out to look for the documentation of the title or any information about the basis of it in the land and mortgage registers, cadaster, national archives, etc. Many governments share a common problem; they do not know where and how much public property they own and what rights are attached to it, where all of the existing information is located in a complex institutional environment, and how complete, accurate, reliable and relevant the information is for planning and 
decision-making (FAO 2008). This causes the situation of public property assets being mismanaged, and underutilized. In some countries, the lack of the above mentioned documentation also concerns the assets of individuals and derives from the losses incurred during warfare. In Syria, for example, the loss, destruction, or absence of property documents has left many refugees and internally displaced people unable to prove the ownership of land that has been in their family for generations (Stubblefield \& Joireman, 2019). If refugees do not have copies of such documents, their ability to reclaim the property depends on the survival of the registries. In a study of 580 Syrian refugee households conducted by the Norwegian Refugee Council (...), the majority (50\%) were not in possession of such documents or believed that the documents they had left behind had been destroyed (20\%) (Cunial, 2016). Occasionally, there are situations when a parcel is presented in a cadaster as non-mortgaged land, even though a land and mortgage register had, in fact, been established and the right of ownership published therein. The aim is, to identify which land and mortgage register is maintained for the analyzed property. An example of a map for legal purposes prepared for the needs of regulating the legal status of a property registered in a cadaster as the real estate of an unknown owner has been shown in Fig. 1. Some elements of the content of the map have been indicated in color and marked based on the description (A-G) used in Table 1.

Figure 1

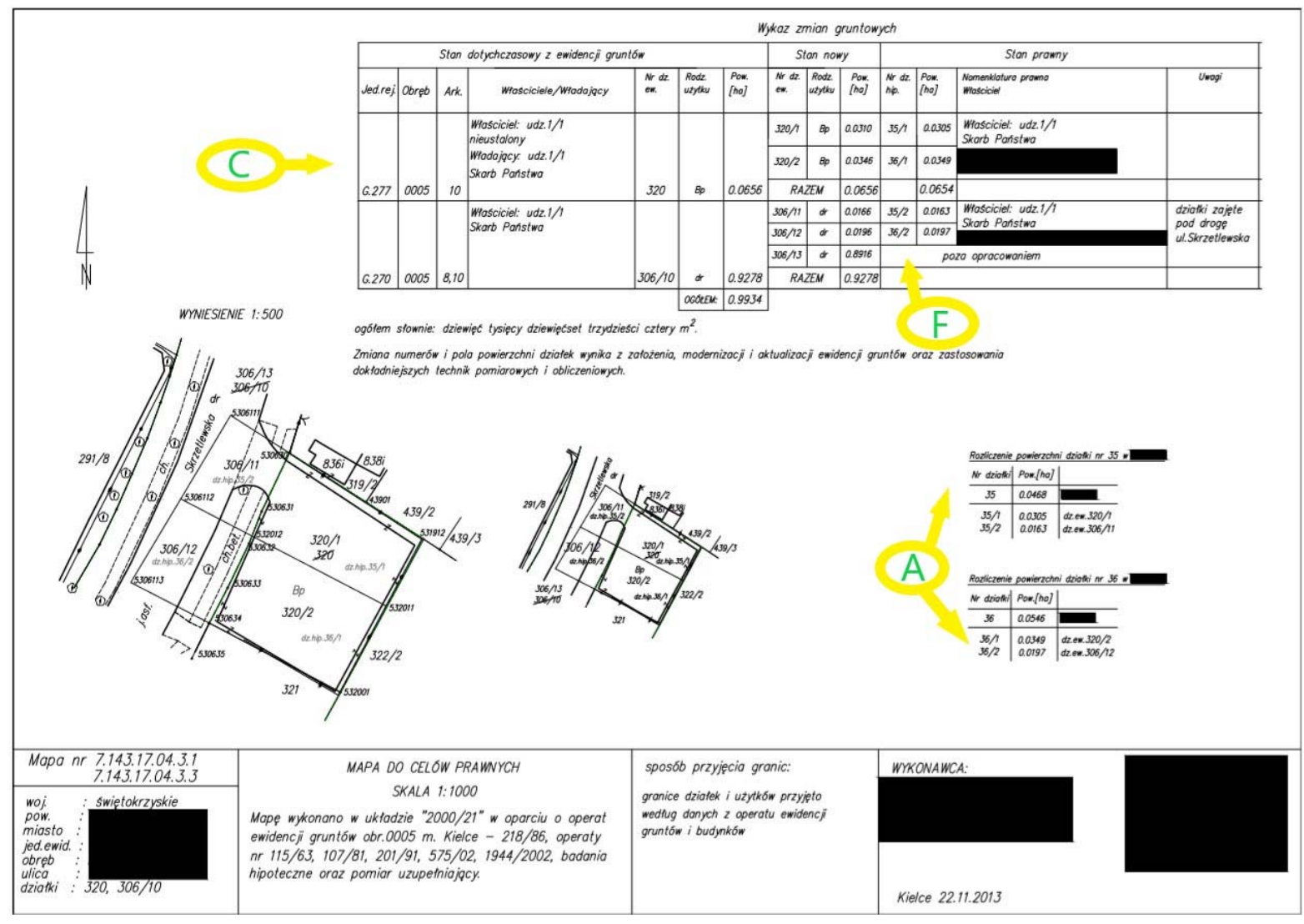

Fig. 1. Example of a map for legal purposes prepared for the needs of regulating the legal status of a property. Source: own work.

There are also situations when the title to the property has already been acquired (for example by virtue of law), but it has to be ascertained in the administrative or court proceedings. There are several manners on the basis of which the State Treasury and local government units acquire property rights. The simplest way to regulate the legal status and to obtain the title to ownership of a real property by its possessor is acquisitive prescription. A real property holder acquires the right as of the end of the last day of the period provided for in Article 172 of the Act of 23 April 1964 - the Polish Civil Code, i.e. after twenty years of uninterrupted possession of a real property in the case of acting in good faith or thirty years in bad faith. According to Article 3 Section 2 of the Act of 7 September 2007 on publishing 
the right of ownership to the real estate of the Treasury and of territorial self-government units in land and mortgage registers, if the basis for entry of ownership of real estate owned by the State Treasury in land and mortgage registers, in accordance with separate provisions, constitutes a court verdict stating the acquisition of real property by virtue of law, the provisions of the Act of 17 November 1964 - the Code of Civil Procedure on the statement of acquisitive prescription apply respectively. It is then necessary to develop surveying and legal documentation and apply for confirmation of purchase of real estate in the court. In Greece, the period needed to acquire a property by us caption is 20 years for private land, though this does not apply to State land. If the occupation of the land is not peaceful, or if even an amount as little as one peppercorn is paid in rent to the true owner, then the absolute rights cannot be acquired by such means (United Nations 2004). In Australia, there are a number of common law requirements for a successful adverse possession claim; typically, the following common law elements are required: exclusive - continuous and uninterrupted possession; possession must be adverse to the interests of the legal owner and without permission of the legal owner; open and notorious - using the land in a manner so as to place the legal owner on notice that a trespasser is in possession; and for a defined period of time - a statute of limitations applies for a definite period of time which limits the action taken by the legal owner to recover the land to that period of time (Simmons, 2010). In order to successfully apply for acquisitive prescription in the United Kingdom, the applicant must meet certain requirements: actually hold the property for the required period and demonstrate constructive possession of that property (also called possession in law - the ability to exercise control over the property, even without physical contact with it) (Trembecka, 2019). The owner loses the right to land that they do not hold after a lapse of 12 years (with some exceptions such as: 30 years - for land owned by the Crown or the Anglican Church, 60 years - for waterfront land owned by the Crown, etc.), which deprives them of the possibility of requesting its release by the possessor.

The standard is that, for the needs of the surveying documentation, it is necessary to reconstruct the location of boundaries as on the day of the right acquisition (E). The reconstruction of boundaries is an important task, as they are an element of the definition of the right of ownership, limiting the area in which the owner can benefit from their rights. Land surveyors very often need to examine documents concerning the location of boundaries gathered in the state geodetic and cartographic resource after the occurrence of changes over the years. Frequently, the location of boundaries from before many years or even from the post-war period is examined. It is then vital to reconstruct the location of boundary markers and boundary lines on the basis of archive documents. In Poland, from the times of the Russian partition, a small number of source cartographic and descriptive materials have survived and, what is more, the materials that have survived to this day have a low cartometric value (Przewięźlikowska \& Skotnicki, 2001). The situation is completely different, however, in the areas of the former Prussian partition, where large numbers of such documents are available and the area covered by them is larger. Mączyńska (2018) carried out research on the usefulness of the pre-war consolidation maps in the activities aiming at determining borders in areas of the former Russian partition. During the field work carried out, it was noticed that field construction points have survived to this day, despite the stabilization that took place 80 years ago. Moreover, the data contained in the land and buildings register database used to be collected by different methods and at different periods, so the database can contain data of varying quality (Hanus, et al., 2018). It turns out that, in many cases, the reliable reconstruction of quantitative and qualitative information concerning a given area or an object from many years earlier is very hard or even impossible. The prepared documentation of results, very often contains a synchronization list (F) and, if necessary, also a list of land-use changes (C) - in the case where it is necessary to divide plots. When there is no need to subdivide a property - the whole parcel is the subject of proceedings, a so-called measurement register (D) is drawn up. Subdivision is crucial, especially when the subject of acquisitive prescription does not encompass the entire parcel on record. It is necessary to prepare it, among other cases, when a part of a parcel is the subject of proceedings.

- errors in the entries in land and mortgage registers - in the separation of real estates, in their inclusion into other registers and in the settlement of their area

Among the analyzed twenty cases for the following publication, one of the major problems were errors in the entries in land and mortgage registers $(20 \%)$ demanding their verification $(G)$. In Poland, changes in the rules of the registration, as well as negligence in the management of public real estates have led to many inconsistencies in the contents of the entries. A frequently encountered 
problem is double mortgaging (B). In the case of the analyzed twenty tasks, this was noted in $15 \%$ of the cases. This involves disclosing the right to the same real estate in more than one land and mortgage register. When verifying such cases, it is often crucial to find errors in the division of real estates from land and mortgage registers, in their inclusion into other registers and in the settlement of their area. All this affects the extension of the time for the completion of the provisions of the Act of 7 September 2007 on publishing the right of ownership to the real estate of the Treasury and of territorial self-government units in land and mortgage registers. The content of land and mortgage register needs to be studied together with the documentation constituting the basis for designation. As the numbering of parcels has changed very often over the years, a licensed surveyor prepares a settlement of mortgage plots (A), presenting which mortgage parcel corresponds to which current plots. Sometimes, due to mistakes in updates made to the land and mortgage register, the plot is no longer recorded in it even though it should be. All such situations demand regulation.

An example of a map for legal purposes prepared for the needs of regulation of the legal status of double mortgaged properties has been shown in the Fig. 2. Some elements of the contents of the map have been indicated in color and marked based on the description (A-G) used in Table 1.

Figure 2

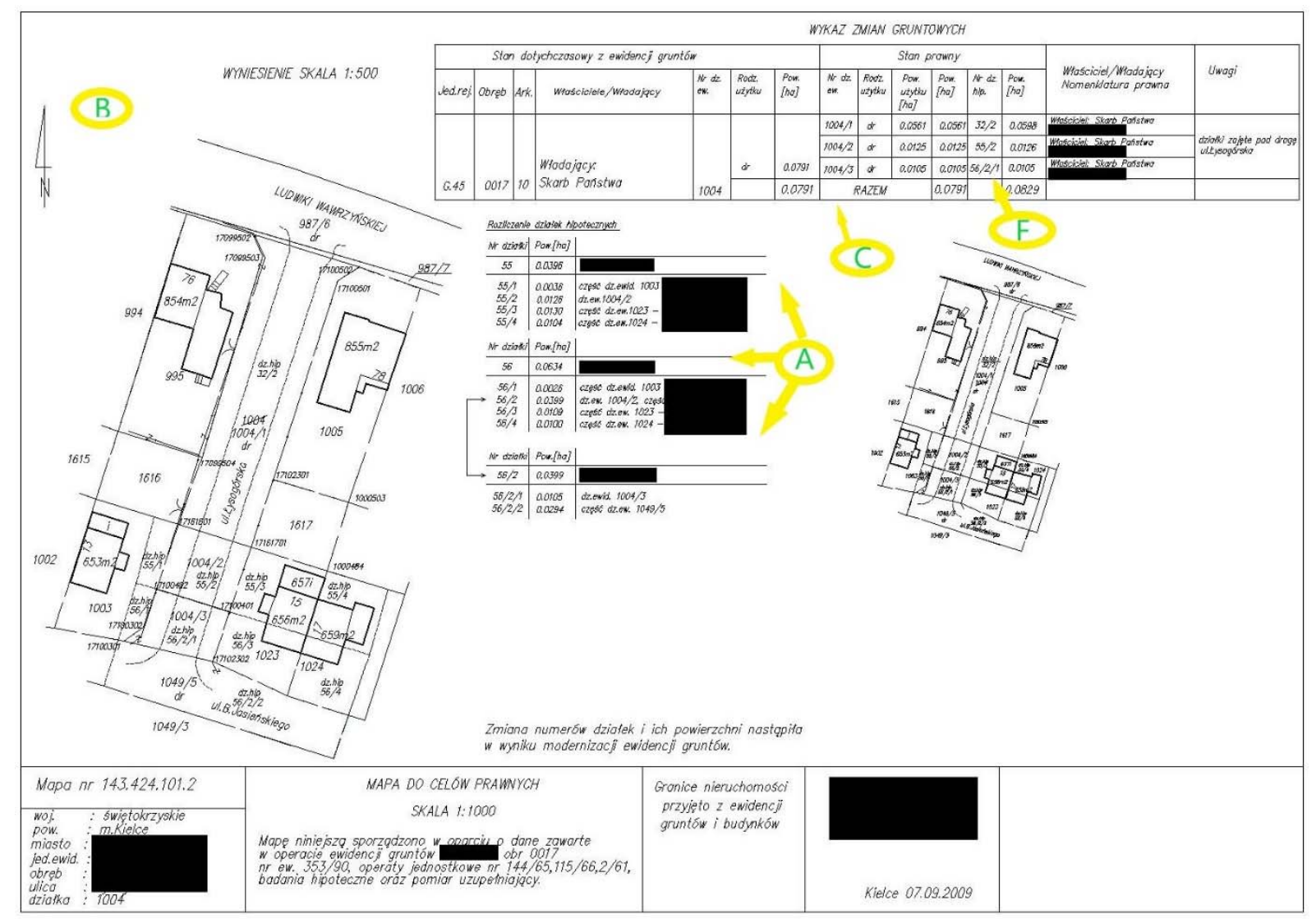

Fig. 2. Example of the map for legal purposes prepared for the needs of regulation of legal status of double mortgaged properties. Source: own work.

\section{Discussion and conclusions}

Land management of the public assets is a very important issue influenced, among others, by the specifics of the country, its politics and the amount of public resources. Lack of proper knowledge on the quantity of public land, legislation related to its management and negligence in updating entries in registers have a bad influence on both social and economic matters. There is widespread recognition that good land records ensure, among others, security of tenure, fairness in taxation and efficient resource management. The separation of the two registers - land and mortgage registers and the cadaster - in Poland in connection with their inadequate linkage is one of the major problems affecting the unregulated legal status. Some of the problems pointed out will be avoided if the Integrated Real 
Estate Information System is introduced. The documentation prepared by licensed surveyors plays a crucial role in the regulation process of the legal status of properties, seeing as how it provides rightful identification of the problem in a lot of cases as well as a solution. As shown by the above-mentioned twenty cases demanding maps for legal purposes, making a synchronization list, subdividing parcels, and preparing the settlement of mortgage plots are the most common activities in the process of preparing surveying legal documentation for court proceedings. The research shows that the process is complex and usually consists of a series of the selected, repeated activities. Due to the fact that the most common actions performed in the process and the most frequent contents of the maps may be distinguished, a standard procedure for regulating the legal status of properties can be worked out. All of this requires practical knowledge and depends on the quality and availability of documentation.

\section{References}

Aien, A., Rajabifard, A., Kalantari, M., \& Wiliamson, I. P. (2017). Review and Assessment of Current Cadastral Data Models for 3D Cadastral Applications, Advances in 3D Geoinformation. Melbourne, Australia. https://doi.org/10.1007/978-3-319-25691-7_24

Bończak-Kucharczyk, E. (2011). Ustawa o ujawnianiu w księgach wieczystych prawa własności nieruchomości Skarbu Państwa oraz jednostek samorządu terytorialnego (Act of 7 September 2007 on disclosing in the land and mortgage registers the ownership rights to real estates of the State Treasury and local government units). Wolters Kluwer Polska.

Buśko, M., \& Przewięźlikowska, A. (2016). The problem of demonstrating cadastral changes in surveying documentation. Geographic Information Systems Conference and Exhibition - GIS ODYSSEY, Perugia, Italy.

Bydłosz, J. (2015). The application of the Land Administration Domain Model in building a country profile for the Polish cadaster. Land Use Policy, 49, 598-605. https://doi.org/10.1016/j.landusepol.2015.02.011

Bydłosz, J., Bieda, A., \& Parzych, P. (2018). The Implementation of Spatial Planning Objects in a 3D Cadastral Model. ISPRS International Journal of Geo-Information, 7(4), 153. https://doi.org/10.3390/ijgi7040153

Celarek, K. (2012). Problematyka prawna nieruchomości Skarbu Państwa - wybrane zagadnienia (Legal issues of real estate of the Treasury - selected issues). Towarzystwo Naukowe Nieruchomości.

Cienciała, A., \& Florek-Paszkowski, R. (2016). Abandoned properties in the processes of real estate management in Poland. Geographic Information Systems Conference And Exhibition - Gis Odyssey.

Cienciała, A., \& Sobolewska-Mikulska, K. (2017). Problematyka geodezyjno-prawna w procesie ustalania stanu prawnego nieruchomości w Polsce (Surveying and legal issues in the process of determination of the legal status of real estates in Poland). Oficyna Wydawnicza Politechniki Warszawskiej.

Cunial, L. (2016). Briefing Note: Housing, Land and Property in the Syrian Arab Republic. Norwegian Refugee Council.

Dawidowicz, A., \& Źróbek, R. (2017). Land administration system for sustainable development - case study of Poland. Real Estate Management and Valuation, 25(1), 112-122. https://doi.org/10.1515/remav-2017-0008

Dawidowicz, A., \& Źróbek, R. (2018). A methodological evaluation of the Polish cadastral system based on the global cadastral model. Land Use Policy, 73, 59-72. https://doi.org/10.1016/j.landusepol.2018.01.037

Demir, O., Uzun, B., \& Çete, M. (2008). Turkish cadastral system. Survey Review, 40(307), 54-66. https://doi.org/10.1179/003962608X253484

Drobež, P., Fras, M. K., Ferlan, M., \& Lisec, A. (2017). Transition from 2D to 3D real property cadastre: The case of the Slovenian cadastre. Computers, Environment and Urban Systems, 62, 125-135. https://doi.org/10.1016/j.compenvurbsys.2016.11.002

Eliseev, I. N., Hernik, J., \& Noszczyk, T. (2015). The change of the purpose of agricultural lands for nonagricultural in Russia and Poland. Acta Scientiarum Polonorum. Formatio Circumiectus, 13(4), 5564. https://doi.org/10.15576/ASP.FC/2014.13.4.55

Evtimov, V. (2002). The Bulgarian Cadastre and Property Register Act and the Pertinent Project. FIG XXII International Congress, Washington, D.C. USA.

Grover, R. (2008). Why the United Kingdom does not have a cadastre - and does it matter? Annual Meeting 2008 FIG Commission 7, Verona, Italy. 
Grzesik, K., Hałgas, M., \& Kostański, P. (2007). Prawo rzeczowe (Property law). Wydawnictwo C.H.Beck, Warsaw.

Choi, H. O. (2020). An Evolutionary Approach to Technology Innovation of Cadastre for Smart Land Management Policy. Land (Basel), 9(2), 50. https:// doi.org/10.3390/land9020050

Hanus, P., Pęska-Siwik, A., \& Szewczyk, R. (2018). Spatial analysis of the accuracy of the cadastral parcel boundaries. Computers and Electronics in Agriculture, 144, 9-15. https://doi.org/10.1016/j.compag.2017.11.031

Holtslag-Broekhof, S. M., Van Marwijk, R., Beunen, R., \& Wiskerke, J. S. C. (2016). Perceived justice of Public Land Acquisition. Journal of Agricultural \& Environmental Ethics, 29(2), 167-184. https://doi.org/10.1007/s10806-015-9594-3

Kaczorowska M., (2018). Informatisation of Land Registers in Poland and Other Member States of the European Union. A Comparative Overview. Law and Forensic Science, 17 (2019/1).

Klimach, A., Dawidowicz, A., \& Źróbek, R. (2018). The Polish land administration system supporting good governance. Land Use Policy, 79, 547-555. https://doi.org/10.1016/j.landusepol.2018.09.003

Kocur-Bera, K., \& Stachelek, M. (2019). Geo-Analysis of Compatibility Determinants for Data in the Land and Property Register (LPR). Geosciences, 9(7), 303. https://doi.org/10.3390/geosciences9070303

Kotlarz, P. (2017). Analysis of the influence of the quality of cadastral data on the process of surveying works in Poland. Geographic Information Systems Conference and Exhibition - Gis Odyssey.

Kwartnik-Pruc, A., Hanus, P., \& Owerko, T. (2012). Wykaz synchronizacyjny jako podstawowy dokument regulacji stanu prawnego nieruchomości (Synchronization list as a basic document regulating the legal status of a real estate). Infrastruktura i Ekologia Terenów Wiejskich, 1, Kraków.

Kwartnik-Pruc, A. (2015). Possibilities Of Using Innovative Sources Of Information On Real Estate In The Spatial Data Collection Process. Real Estate Management and Valuation, 23(1), 103-113. https://doi.org/10.1515/remav-2015-0010

Łuczyński, R. (2010). Dokumentacja geodezyjno-prawna w regulacjach stanów prawnych istniejących dróg publicznych (Surveying and legal documentation in the regulation of the legal status of existing public roads). Przegląd Geodezyjny, 82(12), Warszawa.

Mączyńska, A. (2018). Usefulness Analysis of Pre-War Consolidation Maps in Selected Procedures Determining Course of Borders on Example of Matyniów and Czarniecka Góra Units. Geomatics and Environmental Engineering 12.

Noszczyk, T., \& Hernik, J. (2019). Understanding the cadastre in rural areas in Poland after the sociopolitical transformation. Journal of Spatial Science, 64(1), 73-95. https://doi.org/10.1080/14498596.2017.1404500

Osskó, A. (2008). The Multipurpose Hungarian Unified Land Registry System. Integrating Generations FIG Working Week 2008, Stockholm, Sweden.

Passador, L. (2012). Correspondence between maps of Italian cadastre and Austrian Libro Fondiario legal value and process of update. FIG Working Week 2012, Rome, Italy.

Polat, Z. A., Alkan, M., \& Sürmeneli, H. G. (2017). Determining strategies for the cadastre 2034 vision using an AHP-Based SWOT analysis: A case study for the turkish cadastral and land administration Lystem. Use Policy, 151-166. https://doi.org/10.1016/j.landusepol.2017.05.004

Potsiou, C., Paunescu, C., Ioannidis, C., Apostolopoulos, K., \& Nache, F. (2020). Reliable 2D Crowsourced Cadastral Surveys: Case studies of Greece and Romania. International Journal of GeoInformation, 9, 89. https://doi.org/10.3390/ijgi9020089

Przewięźlikowska, A., \& Skotnicki, K. (2001). The application of Prussian, German and Russian cadastral source materials for contemporary needs, selected surveying works and legal issues (Wykorzystanie pruskich i niemieckich oraz rosyjskich źródłowych materiałów katastralnych dla potrzeb współczesnych, wybranych prac geodezyjnych i zagadnień prawnych). Geodezja 7, 73-86.

Puniach, E., Bieda, A., Ćwiąkała, P., Kwartnik-Pruc, A., \& Parzych, P. (2018). Use of unmanned aerial vehicles (UAVs) for updating farmland cadastral data in areas subject to landslides. ISPRS International Journal of Geo-Information, 7(8), 331. https://doi.org/10.3390/ijgi7080331

Rabenhorst, C. S. (2000). The real estate market in Bosnia-Harzegogovina. Current status and Recommendations for Reform. The Urban Institute. 
Radulović, A., Sladić, D., \& Govedarica, M. (2017). Towards 3D Cadastre in Serbia: Development of Serbian Cadastral Domain Model. ISPRS International Journal of Geo-Information, 6(10), 312. https://doi.org/10.3390/ijgi6100312

Renigier-Biłozor, M. (2017). Modern classification system of real estate markets. Geodetski Vestnik, 61(03), 441-460. https:// doi.org/10.15292//geodetski-vestnik.2017.03.441-460

Rudnicki, S. (2005). Ustawa o ksiegach wieczystych $i$ hipotece. Przepisy o postępowaniu w sprawach wieczystoksiegowych. Komentarz (The act on land and mortgage registers and mortgage. Provisions on the procedure in land and mortgage register issues). LexisNexis.

Simmons, S. (2010). Part-Parcel Adverse Possession as a Means to Resolving Problem Survey Areas. FIG Congress, Sydney, Australia,

Sobolewska-Mikulska, K. (2014). Gospodarka nieruchomościami i kataster. Wybrane problemy (Real estate management and cadastre. Selected problems). Oficyna Wydawnicza PW, Warsaw.

Stoter, J., Ploeger, H., Roes, R., Riet, E., Biljecki, F., Ledoux, H., Kok, D., \& Kim, S. (2017). Registration of Multi-Level Property Rights in 3D in The Netherlands: Two Cases and Next Steps in Further $\begin{array}{lllll}\text { Implementation. International Journal of Geo-Information, 6(6), } 158 . & \text { r }\end{array}$ https://doi.org/10.3390/ijgi6060158

Stubblefield, E., \& Joireman, S. (2019). Law, Violence, and Property Expropriation in Syria. Impediments to Restitution and Return, 8(11), 173.

Trembecka A., (2019). Analysis of Possible Cases of Acquisitive Prescription of Public Properties Presented on Example of Selected Area. Geomatics and environmental engineering, 13(2), 73-82. https://doi.org/10.7494/geom.2019.13.2.73

Ulger, N. E., Yildirim, C., \& Iban, C. (2015). Evaluation on Current Turkish Cadastral Systems in Accordance with FIG Cadastre 2014 Statements. FIG Working Week 2015 From the Wisdom of the Ages to the Challenges of the Modern World, Sofia, Bulgaria.

UNECE. (2004). Guidelines on real property units and identifiers. Economic Commission for Europe.

UNECE. (2005). Land administration in the UNECE Region. Development trends and main principles, New York and Geneva.

Ustawa z 21 sierpnia 1997 r. o gospodarce nieruchomościami, Dz. U. z 1997 r. nr 115, poz. 741 z późn. zm. (Act of 21 August 1997 on Real Estate Management, Journal of Laws, 1997, no. 115, item 741 as amended).

Ustawa z 6 lipca 1982 r. o księgach wieczystych i hipotece, Dz. U. z 1982 r. nr 19, poz. 147 z późn. zm. (Act of 6 July 1982 on land and mortgage registers and mortgage, Journal of Laws, 1982, no. 19, item 147 as amended).

Ustawa z 7 września 2007 r. o ujawnianiu w księgach wieczystych prawa własności nieruchomości Skarbu Państwa oraz jednostek samorządu terytorialnego, Dz. U. z 2007 r. nr 191, poz.1365 z późn. zm. (Act of 7 September 2007 on disclosing in the land and mortgage registers the ownership rights to real estates of the State Treasury and local government units, Journal of laws, 2007, no. 191, item 1365 as amended). 